\title{
Interactional Metadiscourse in Research Articles Written by Turkish and
}

\author{
Native Speakers ${ }^{1}$
}

\author{
Meral ÇAPAR ${ }^{2}$, Ümit Deniz TURAN ${ }^{3}$
}

\begin{abstract}
This study investigates how Turkish non-native speakers and native speakers of English use metadiscourse markers in research articles. With this purpose, a total of 100 research articles on the field of teaching a foreign language were analyzed based on the taxonomy of Hyland and Tse (2004). 50 research articles written by Turkish academic writers and 50 research articles written by American academic writers were collected from prestigious journals. The taxonomy has mainly two components: Interactive and interactional resources. This study focuses on the interactional resources. A qualitative approach was applied. The results of the binomial test showed that there are significant differences in the use of interactional metadiscourse markers between the two groups. American academic writers (AAWs) used significantly more interactional metadiscourse markers (IMMs) in English research articles (ERAs) compared to Turkish academic writers (TAWs). The use of the subcategories of engagement markers were also significantly different specifically in terms of the use of self-mention and questions. This may suggest that the use of IMMs may show cultural preferences, which can be considered as stylistic difference and may not need further instructional intervention. Thus, academic writing courses are suggested to be included especially in MA and PhD programs. Models of academic texts can be used in courses and raising consciousness on both micro and macro aspects of academic discourse can be suggested.
\end{abstract}

Keywords: Academic writing, research articles, interactional metadiscourse markers, EFL writing

\footnotetext{
1 Anadolu University Institute of Educational Sciences, the scope of English Language Teaching Doctoral Program, This research is produced from the thesis titled "Interactional Metadiscourse Markers in Research Articles" prepared under the supervision of Prof. Dr. Ümit Deniz TURAN.

${ }^{2}$ Anadolu University, Faculty of Education, Department of Foreign Languages, e-mail: meralceylan@anadolu.edu.tr, ORCID: 0000-0003-2884-1971

${ }^{3}$ Anadolu University, Faculty of Education, Department of Foreign Languages, e-mail: udt@anadolu.edu.tr, ORCID:0000-0002-7163-2377
} 
AJESI - Anadolu Journal of Educational Sciences International, 2020; 10(1): 324-358

DOI: 10.18039/ajesi.682042

\section{Introduction}

Since the onset of globalization, writing has become an important aspect of communication, and English, as a lingua franca, is the most widespread language used in every aspect of communication, including academic research papers. Academic research papers have their own idiosyncratic ways of argumentation with the aim of persuading the reader and for interacting with the reader. In research articles, data must be organized by writers into meaningful patterns for readers. With these conventional patterns of academic discourse, part of an academic's competence includes familiarity with these practices of a particular disciplinary community (Swales, 1990).

In order to be able to interact with the target community, academic writers can make use of metadiscourse with basically two aims; first, to assist readers in processing text, to encode relationships between ideas and present the components of their research coherently and convincingly so that readers can find the study appropriate and reasonable. The second aim of using metadiscourse markers is attending the need to focus on the participants of the interaction (Hyland, 1998). In research articles, writers aim at providing metadiscourse knowledge construction through managing interaction between writers and readers who share cultural, academic, and rhetorical practices. Through metadiscourse, it is possible for writers to strengthen their claims and to have them accepted by their readers (Hyland, 2005). Considering the importance of metadiscourse markers in research articles, the aim of this study is to explore the use of interactional text markers in English Research Articles (henceforth ERAs) written by American and Turkish writers and to contribute to genre studies and the teaching of academic writing. In addition, it is expected to contribute to the field of applied linguistics since very few contrastive studies have been carried out on the interactional metadiscourse use of Turkish and American academic writers (Alg1, 2012; Can, 2006; Doyuran, 2009; Kafes, 2009). 
AJESI - Anadolu Journal of Educational Sciences International, 2020; 10(1): 324-358

DOI: 10.18039/ajesi.682042

Different languages and different writing traditions show variations to an important degree and this may lead to cross-cultural misunderstanding in scientific communication (Kreutz and Harres, 1997; Vassileva, 2001; Ventola, 1997). Each culture might have its own norms, values, languages as well as ways of communication (van Dijk, Ting-Toomey, Smitherman, Troutman, 1997); thus, what may be acceptable in one language may not be in another (Hyland, 2005). L1 and L2 writers can have different methods for organizing their ideas and interacting with their readers, and these patterns can be transferred from the native language to the foreign language (Chesterman, 1998). It has been shown in the literature that there is a plethora of problems experienced by non-native academic writers while writing in a foreign language for publication in the field of applied linguistics (Flowerdew, 1999; Kaplan and Baldauf, 2005; St. John, 1987) as well as in science (Benfield and Feak, 2006; Benfield and Howard, 2000). Turkish academic writers need to write their research articles in English in order to share their studies in the international community of researchers. Contrastive studies can shed light on teachers' understanding of the differences between the students' native culture and the culture of the discourse community under discussion (Hyland, 2005). The current study can contribute to teachers to help their learners to build on their own voice while writing English academic texts.

This study is further expected to provide ideas for the development of an advanced writing syllabus in the teaching ESP (English for Specific Purposes), EAP (English for Academic Purposes) and EFL (English as a Foreign Language).

\section{Metadiscourse Taxonomy}

Metadiscourse is seen as one of the significant rhetorical features and strategies in producing discourse (Chambliss and Garner, 1996; Hyland, 1998). An academic text, as texts in other genres, should contain some communicational aspects through metadiscourse 
AJESI - Anadolu Journal of Educational Sciences International, 2020; 10(1): 324-358

DOI: 10.18039/ajesi.682042

markers in order for readers to follow the text. Metadiscourse markers help to organize the discourse, engage the audience and signal the writers' attitudes (Zarei, 2011). Metadiscourse is considered as a part of academic rhetoric, which can be influenced by the culture of the writer (Halliday, 1994). For example, while in some cultures it is acceptable to use the imperative form to guide the reader within the text such as "(see table 1)", in other cultures it sounds authoritative and/or impolite.

The first inclusive functional classification of metadiscourse was presented by Vande Kopple (1985). Two main categories were suggested; textual and interpersonal. Textual metadiscourse is also referred to as metatext (Bunton, 1999; Mauranen, 1993) and it fulfills Halliday's textual function by organizing the text and directing the reader.

Crismore and Farnsworth (1989) state that people often make use of metadiscourse markers while using a language because they select options within three semantic systems suggested by Halliday (1973). Metadiscourse performs the textual and interpersonal functions of language. According to Halliday (1973), there are three macro-functions of language: the ideational (expressing referential information about the world), the interpersonal (showing how authors or speakers interact with their readers and listeners), and the textual (shaping language into a connected text). In general, metadiscourse taxonomies (Vande Kopple, 1985; Crismore, Markkanen and Steffensen, 1993; Mauranen, 1993; Bunton, 1999) are based on these three macro-functions of language suggested by Halliday (1973).

Hyland and Tse (2004) suggested a model for metadiscourse taxonomy based on the results of their study on academic writing. According to Hyland and Tse, metadiscourse shows how writers are aware of a text as discourse and how they use the language to include a text, a writer and a reader.

In the taxonomy suggested by Hyland and Tse, there are two main dimensions: interactive and interactional. As shown in Table 1, interactive resources act as a guide to the 
AJESI - Anadolu Journal of Educational Sciences International, 2020; 10(1): 324-358

DOI: 10.18039/ajesi.682042

reader through the text, while interactional resources are used in order to involve the reader in the argument. By using interactional resources, the writer has the opportunity to express himself with the help of textual 'voice' or community-recognized personality. Also, he can comprise the ways in which he expresses judgments and connects to the readers. The present study is based on the interactional resources in this metadiscourse taxonomy suggested by Hyland and Tse (2004) and as shown in Table 1, hedges, boosters, attitude markers, selfmentions, and engagement markers are considered to be interactional resources.

Table 1

Metadiscourse Taxonomy by Hyland and Tse (2004)

\begin{tabular}{|c|c|c|c|}
\hline Category & & Function & Examples \\
\hline \multirow{5}{*}{$\begin{array}{l}\text { Interactive } \\
\text { Resources } \\
\text { help to guide } \\
\text { reader } \\
\text { through the } \\
\text { text }\end{array}$} & Transitions & $\begin{array}{l}\text { Express semantic relation } \\
\text { between main clauses }\end{array}$ & In addition/but/thus/and \\
\hline & Frame markers & $\begin{array}{l}\text { Refer to discourse acts, } \\
\text { sequences, or text stages }\end{array}$ & $\begin{array}{l}\text { Finally/to conclude/my } \\
\text { purpose is to }\end{array}$ \\
\hline & Endophoric markers & $\begin{array}{l}\text { Refer to information in other } \\
\text { parts of the text }\end{array}$ & $\begin{array}{lll}\text { Noted } & \text { above/see } & \text { Fig./in } \\
\text { Section } 2 & & \end{array}$ \\
\hline & Evidentials & $\begin{array}{l}\text { Refer to source of information } \\
\text { from other texts }\end{array}$ & $\begin{array}{l}\text { According to } \mathrm{X} /(\mathrm{Y}, 1990) / \mathrm{Z} \\
\text { states }\end{array}$ \\
\hline & Code glosses & $\begin{array}{l}\text { Help readers grasp meanings } \\
\text { of ideational material }\end{array}$ & $\begin{array}{l}\text { Namely/e.g./such as/in other } \\
\text { words }\end{array}$ \\
\hline \multirow{5}{*}{$\begin{array}{l}\text { Interactional } \\
\text { Resources } \\
\text { involve the } \\
\text { reader in the } \\
\text { argument }\end{array}$} & Hedges & $\begin{array}{l}\text { Withhold writer's full } \\
\text { commitment to proposition }\end{array}$ & $\begin{array}{l}\text { Might/perhaps/possible/ } \\
\text { about }\end{array}$ \\
\hline & Boosters & $\begin{array}{l}\text { Emphasize force or writer's } \\
\text { certainty in proposition }\end{array}$ & In fact definitely/it is clear that \\
\hline & Attitude markers & $\begin{array}{l}\text { Express writer's attitude } \\
\text { Proposition }\end{array}$ & $\begin{array}{l}\text { Unfortunately/I } \\
\text { agree/surprisingly }\end{array}$ \\
\hline & Engagement markers & $\begin{array}{l}\text { Explicitly refer to or build } \\
\text { relationship with reader with } \\
\text { devices such as directives, } \\
\text { reader pronouns, personal } \\
\text { asides, questions. }\end{array}$ & $\begin{array}{l}\text { Consider/note that/you can see } \\
\text { that }\end{array}$ \\
\hline & Self-mentions & Explicit reference to author(s) & I/we/my/our \\
\hline
\end{tabular}

As seen in Table 1, interactive devices help to guide the reader in the unfolding of the text, such as transitions (such as in addition, but, etc.); frame markers (such as finally, to repeat, etc.); endophoric markers by which the writer leads the reader to a table or a previous 
AJESI - Anadolu Journal of Educational Sciences International, 2020; 10(1): 324-358

DOI: 10.18039/ajesi.682042

argumentation, definition, etc. given in the text; evidentials, which provide the source of information, such as citations; code glosses that help the reader grasp the meaning better (such as in other words, etc.). The interactional metadiscourse markers are the second category, by which the writer leads the reader to help in guiding through the text. This category contains (hedges, boosters, attitude and engagement markers, and self-mention). The category of interactional markers are further defined and discussed in Results Section with some detail.

Metadiscourse has been studied in many various fields and types of texts, such as casual conversation (Schiffrin, 1980), in books, such as Darwin's Origins of the Species (Crismore and Farnsworth, 1989), in company annual reports (Hyland, 1998), post-graduate dissertations (Bunton, 1999), introductory course books (Hyland, 1999), slogans and headlines (Fuertes-Olivera, Velasco-Sacristan, Arribas-Bano, and Samaniego-Fernandez, 2001), in academic writing (Hyland and Tse, 2004; Kuhi and Behnam, 2011; Mina and Biria, 2017; Kafes, 2009; Liu and Huang, 2017; Suntara and Chokthawikit, 2018). There have also been studies on metadiscourse in different languages and disciplines (in Finnish, Mauranan, 2001; in Spanish, Valero-Garces, 1996; in French and Norwegian Breivega, Dahl, and Flottum. 2002; in Turkish Kan, 2016).

Effective writing means considering the needs of the readers in terms of conveying the content and involve them in a dialogue (Hyland and Tse, 2004). Hyland (1998) states that in research writing, it is significant to orient the reader to secure rhetorical objectives. The writer needs to make linguistic choices, so that an audience will recognize these choices as persuasive. Effectiveness in making these choices is based on their cognitive and cultural value to the community (Hyland, 1998). The two research questions of the present study is as follows: 
AJESI - Anadolu Journal of Educational Sciences International, 2020; 10(1): 324-358

DOI: 10.18039/ajesi.682042

\section{Research Question}

1. Is there a significant difference in the use of interactional metadiscourse markers in English research articles on teaching English as a foreign language written by TAW and AAW?

2. If so, in what ways do they differ?

Before these questions are answered, the design and methodology of the study are presented in the following section.

\section{Methodology}

This comparative study is based on a qualitative research method. Qualitative research method is an in-depth exploration of a central phenomenon, and in this study, the central focus is interactional metadiscourse elements used in research articles. The data was collected through documents, or more specifically, research articles with experimental designs. Interactional metadiscourse elements in these articles were detected and analyzed in terms of their frequency, meanings and functions.

More specifically, in this study an ethnographic design was used. Ethnographic design is applied when the researcher aims to describe, analyze and interpret a culture-sharing group's shared "patterns of behavior, beliefs and language that develop over time" (Creswell, 2005 ; 436). Since the purpose of this study was to analyze the use of interactional metadiscourse markers of American and Turkish writers in their articles, and report the findings objectively, this study may be called as realistic ethnography.

\section{Data Collection (Pilot Study)}

Before the present study was conducted, a prior pilot study on interactional metadiscourse markers was carried out for the purpose of choosing the disciplinary field for 
AJESI - Anadolu Journal of Educational Sciences International, 2020; 10(1): 324-358

DOI: 10.18039/ajesi.682042

our data collection and investigating the use of interactional metadiscourse elements in ERAs.

The study was carried out with data consisting of eight English research articles written by Turkish non-native speakers and native speakers of English in the field of natural sciences (physics as the representative) and social sciences (education). While analyzing the data, the taxonomy of Hyland and Tse (2004) was taken as a basis.

The first researcher coded and analyzed eight articles by Turkish and English writers manually in order to check whether all the elements of the interactional resources are attested; alternatively whether there are markers that have not been listed by Hyland and Tse (2004). The findings of the pilot study showed that English writers tend to use more interactional elements and more frequently compared to Turkish writers. When the disciplines were compared in both languages, education research articles tend to include more interactional resource elements than physics research articles, and no self-mention use was found in both the education research articles and physics articles.

Based on the data collection, analysis, and the findings of the pilot study, the criteria for coding and analyzing the interactional markers in the study were determined. None of the articles used in the pilot study were included or analyzed in the present study. Since interactional metadiscourse markers were sparse in the natural sciences articles, they were not selected as data for our study, instead language teaching research articles were preferred. The data collection and analyses procedures for the current study are described in the following section.

\section{Data Collection}

This study was carried out based on document analysis (Creswell, 2005; Karasar, 1995; Y1ldırım and Şimşek, 2005). By using documents, the researcher has the opportunity to collect data consisting of the relevant language samples. 
AJESI - Anadolu Journal of Educational Sciences International, 2020; 10(1): 324-358

DOI: 10.18039/ajesi.682042

The sampling type applied in this study is homogenous sampling. In this study, data consists of ERAs written by Turkish and American writers, and British writers were excluded because American and British English research writing conventions may differ in subtle ways. All the research articles in our dataset include experimental studies and they are descriptions of a study conducted in one field; teaching English as a foreign language.

Our data includes 50 ERAs written by Turkish academic writers (TAWs) and 50 ERAs written by American academic writers (AAWs). In total, 100 research articles were examined for interactional text markers.

The research articles were collected from refereed journals, published both online and as hard copies. This would enable the researcher to collect articles with similar writing conventions and language use. The journals were based on education and language teaching. The ERAs by TAWs were selected from refereed journals published internationally because it was important to include articles written in English and accepted internationally. To sum up, the articles and journals were chosen considering the following factors. All articles were:

- on the field of education and English language teaching.

- from refereed international journals.

- from journals published both online and as hard copy.

- from journals cited in Social Sciences Citation Index and British Education Index

The data in this study come from the research articles that were already published in reputable journals accessible to scholars and the authors were informed via e-mail that their articles would be used as our data for language analysis in this study. 
AJESI - Anadolu Journal of Educational Sciences International, 2020; 10(1): 324-358

DOI: 10.18039/ajesi.682042

\section{Data Analysis}

Data was analyzed using NVivo 10, a qualitative computer program and statistics. This program can be used to analyze data collected through qualitative and mixed method research.

While analyzing the data, a descriptive analysis (which is based on frequency use) was used because the researcher used certain predetermined categories for coding the interactional metadiscourse markers. The metadiscourse taxonomy of Hyland and Tse (2004) was used for coding because it is a straightforward and comprehensive model and it is more reader-friendly compared to Vande Kopple's (1989), which is too broad and detailed, and compared to Bunton's (1999), where the taxonomy is divided as text references and level and focus less on interactional metadiscourse markers. Furthermore, Hyland and Tse (2004) is a more comprehensive model because it contains the taxonomies suggested by Vande Kopple (1989) and Bunton (1999). The taxonomy of Hyland and Tse (2004) consists of two main categories; interactive resources and interactional resources; each category with its own subcategories. As has been previously stated, interactional metadiscourse markers (hedges, boosters, attitude markers, engagement markers, and self-mentions) are the focus of the study and they are illustrated in Table 1 above. Based on the data analysis in the pilot study, certain other interactional markers (such as the researcher etc.) were added to the taxonomy.

After the analyses were completed, the figures and tables were formed for per 100.000 words of occurrence of the marker for each data set written by American and Turkish academic writers.

For the reliability of the coding process, an additional English instructor coded $30 \%$ of the data, coding a number of sample articles from each category; English research articles by AAWs and TAWs. The researcher and the English instructor coded a number of sample articles based on the taxonomy, initially together and then separately. 
AJESI - Anadolu Journal of Educational Sciences International, 2020; 10(1): 324-358

DOI: 10.18039/ajesi.682042

The reliability analysis was run on NVivo 10. The program calculated the Kappa Coefficient of the coding comparison for each code in the data and showed agreement for both coders' codes. The reliability coefficients were found to be very high: for the ERAs by TAWs was 91; and for the ERAs by American academic writers, it was again 91.

To compare the findings from the ERAs by the AAWs and the TAWs, a word count of the articles for each group was conducted. Then the number of occurrences per 100,000 words was found for each data set as shown in Table 2. The occurrences of interactional metadiscourse markers in each data set were compared by means of frequencies per 100,000 words (Hyland and Tse, 2004, Hyland, 2004; 2005; Alg1, 2012).

Table 2

Number of Words in Research Articles

\begin{tabular}{lll}
\hline Total Number of Words in the Articles & AAWs & TAWs \\
\hline English Research Articles & 475.930 & 331.248 \\
\hline
\end{tabular}

After revealing the frequencies of each interactional metadiscourse marker, a binomial test was applied to find out whether significant differences existed between the variables. However, some interactional markers (such as remarkable, consider, lack of, etc.) suggested in the taxonomy seem to be too sparse to be represented in 100.000 words and they seem to be " 0 " in Figure $1,2,3,5$, they may be used only once or twice throughout the text. These markers tend to have very low frequency in the data, as a result, they were not included in the statistical analysis.

\section{Results}

As stated above, the aim of this study was to investigate the use of IMMs in ERAs on the teaching English by AAWs and TAWs based on the taxonomy of Hyland and Tse (2004) and modified by the researchers. 
AJESI - Anadolu Journal of Educational Sciences International, 2020; 10(1): 324-358

DOI: 10.18039/ajesi.682042

First, in order to find out whether any significant difference existed in the overall use of IMMs, the frequencies in both data sets were compared. The comparison revealed that the TAWs used interactional metadiscourse markers less frequently in their articles. As shown in Table 3, the total occurrence for IMMs for the TAWs is 491, and for AAWs it is 587 for every 100,000 words. To discover whether this difference in frequency is statistically significant or not, a binomial test was run.

Table 3

Binomial Test Results for the Use of IMMs in ERAs by TAWs and AAWs

\begin{tabular}{lrrr}
\hline & Frequency & qi & z \\
\hline AAWs & 587 & 0.00587 & $2.93187^{*}$ \\
TAWs & & & \\
& 491 & 0.00491 & \\
\hline
\end{tabular}

Table 3 shows that a significant difference was found between the ratios of IMMs used by the TAWs and the AAWs $(z=2.93187, \mathrm{p}<0.05)$. This indicates that interacting with the readers in academic texts may depend on cultural differences. In a similar vein, Zarei (2011) found that Persian writers use less metadiscourse markers compared to native speakers of English in academic texts and Blagojevic (2004) suggested that Norwegian writers use IMMs more frequently while writing English academic texts.

Although there is a significant difference in the overall use of IMMs, a detailed descriptions of the findings of the categories illustrated in Table 1, i.e. hedges, boosters, attitude markers, self-mentions and engagement markers are presented below.

\section{Hedges}

Hedging devices, such as tend to, seem, etc. are used to decrease the level of commitment of the writer. Hedges were used by both writer groups as shown in Table 4, 
AJESI - Anadolu Journal of Educational Sciences International, 2020; 10(1): 324-358

DOI: 10.18039/ajesi.682042

frequency of hedges used by the TAWs outweighs that of the AAWs. The result of a binomial test showed that the difference was not statistically significant $(\mathrm{z}=-1.18415, \mathrm{p}<0.05)$.

Table 4

Binomial Test Results for the Use of Hedges in ERAs by TAWs and AAWs

\begin{tabular}{llll}
\hline & Frequency & qi & z \\
\hline AAWs & 147 & 0.00147 & -1.18415 \\
& 174 & 0.00174 & \\
\hline
\end{tabular}

Considering the frequency of occurrence of hedges in articles, it can be stated that the TAWs preferred to leave their discussions open to their readers' comments and avoided expressing certainty a little more frequently compared to the AAWs. This finding is different from that of Hinkel's study (2005). Hinkel (2005) investigated the types and frequency of hedges in academic essays and found that non-native speakers only made use of a limited range of hedging devices. The hedge markers used by both writer groups are shown in Figure 1.

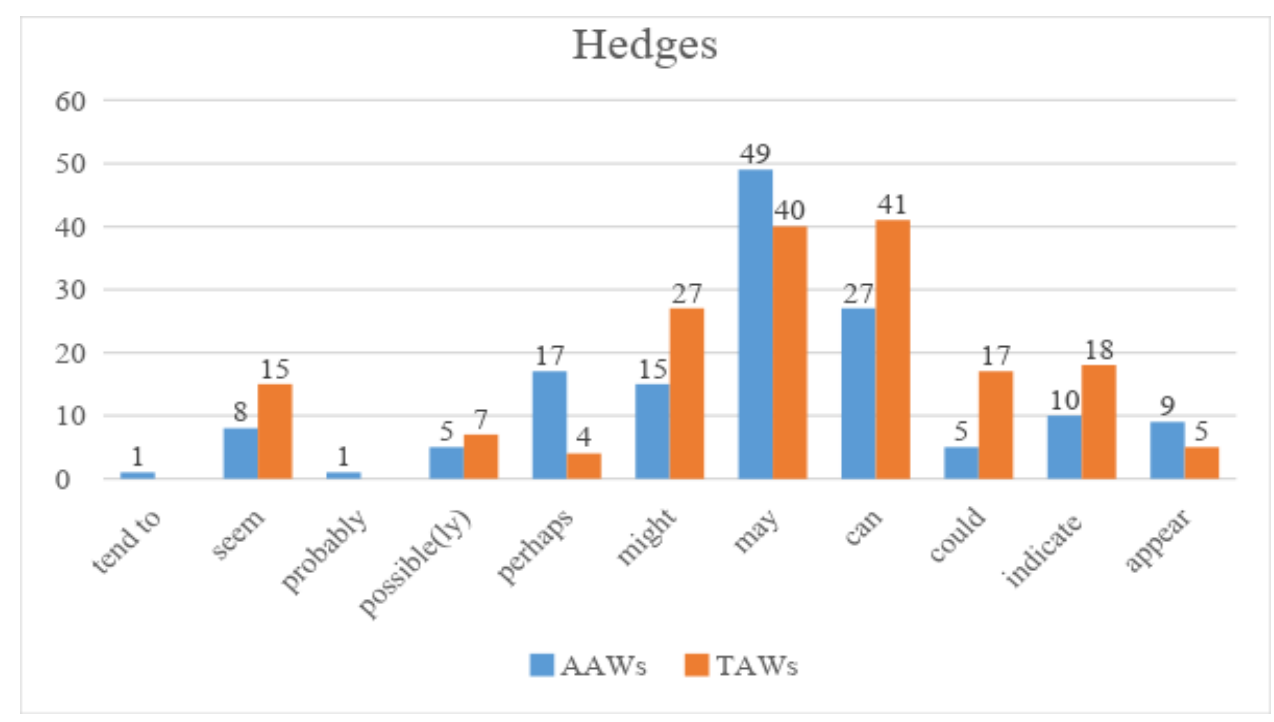

Figure 1: Hedge markers

It can be seen that both writer groups preferred to mark hedging by using modal verbs.

Figure 1 also shows that both writer groups preferred to use may, can, and might more 
AJESI - Anadolu Journal of Educational Sciences International, 2020; 10(1): 324-358

DOI: 10.18039/ajesi.682042

frequently compared to could and other devices such as epistemic verbs (appear) and adjective/adverbs. However, may and can were preferred the most, and the TAWs used them with the same frequency but the AAWs used may as the most frequent hedge marker. This difference may be due to the formality of these modal verbs or that by using may the researcher shows a weaker possibility about the proposition compared to the use of can (Seibel, 1980). It may be interpreted also as the AAWs tended to express more commitment to their propositions compared to the TAWs.

The frequent use of may and can by both sets of writers was also a finding of Kafes (2009). He compared the use of modal verbs to build stance in texts among AAWs, TAWs and Spanish academic writers. He found that both AAWs and TAWs used the modal verb may the most, as does the finding show in this study. In Vold's study (2006) may was found to be used as the most frequent modal verb in medical research articles and Biber, Johansson, Leech, Conrad and Finegan (1999) reveal that may is the most frequent modal verb used to mark logical possibility in academic texts. Additionally, supporting the finding related to the use of may and can, Rezzano (2004) states that may and can are considered as the most productive devices to mark a low degree of certainty in academic texts. In addition, it can be seen that the TAWs used may and can with the same frequency. This may show that the TAWs preferred to use these modals interchangeably.

Another point to be made is the use of perhaps. It can be noticed that the AAWs used this adverb more frequently than the TAWs. The reason may be that the TAWs did not even use the Turkish equivalent of perhaps (belki) in their Turkish research articles (cf. Çapar, 2014); possibly for the reason that it seems less formal in Turkish, and so they may have transferred this habit to their writing in English. Therefore, they used it less frequently and preferred to mark hedging more by the use of may and can. 
AJESI - Anadolu Journal of Educational Sciences International, 2020; 10(1): 324-358

DOI: 10.18039/ajesi.682042

\section{Boosters}

Boosters help writers give an end to alternatives, prevent conflicting opinions and show certainty in what they want to say. Clearly, obviously, and demonstrate are some examples of boosters (Hyland, 2005). The articles written by the AAWs and the TAWs were also compared for the use of boosters. Both writer groups used boosters with similar frequency. The articles by TAWs had 28 and the AAWs 36 occurrences of boosters as shown in Table 5.

Table 5

Binomial Test Results for the Use of Boosters in ERAs by TAWs and AAWs

\begin{tabular}{lrll}
\hline & Frequency & qi & z \\
\hline TAWs & 28 & 0.00028 & -1.00016 \\
AAWs & 36 & 0.00036 & \\
\hline
\end{tabular}

As shown in Table 5, there was no significant difference between the ratios of boosters $(\mathrm{z}=-1.00016, \mathrm{p}<0.05)$. This result may mean that the TAWs tended to write more closely according to the academic writing conventions of the target language they were writing in. In order to discover where the difference lies in terms of frequency, the items used for boosting were compared for the two writer groups as shown in Figure 2.

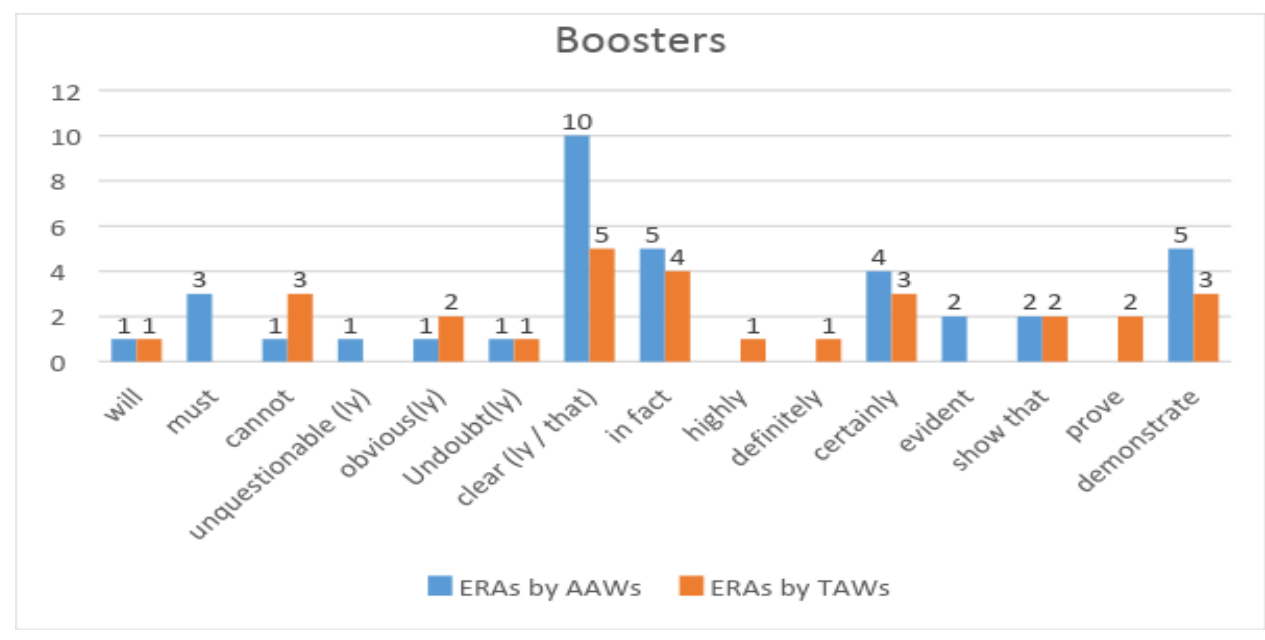

Figure 2: Boosters used in ERAs by TAWs and AAWs 
AJESI - Anadolu Journal of Educational Sciences International, 2020; 10(1): 324-358

DOI: 10.18039/ajesi.682042

Figure 2 shows that both writer groups used clearly and related patterns most frequently in their research articles. However, the AAWs used them twice as frequently. There were ten occurrences of clearly and related patterns found in the ERAs by AAWs, whereas there were only five in the ERAs by TAWs. Moreover, it can be seen that they used in fact, certainly, demonstrate and the modal verb will with similar frequency. Additionally, one item that should be mentioned is the use of the modal must. As Figure 2 shows, although the AAWs used it, none of the TAWs used it. The reason for this may be the strong meaning of must in expressing very high certainty about the proposition. By using must, the writer may show readers that the statement is the writer's view and he does not accept any alternative voice on the issue.

Figure 2 also shows that both writer groups used almost the same variety of verbs and adjectives/adverbs. Furthermore, considering the use of boosters in Turkish research articles, it can be concluded that the TAWs applied the writing conventions of the target language in their research articles (cf. Çapar, 2014).

\section{Attitude Markers}

When writers want to present their affective attitude to propositions, they use attitude markers (Hyland, 2005). Attitude markers are used when surprise, agreement, importance, obligation, frustration and similar emotions need to be shown. The articles of both the TAWs and the AAWs were compared in terms of the use of attitude markers. It was found that the TAWs used attitude markers more frequently than the AAWs. There were 72 occurrences in articles by TAWs and 58 occurrences in the AAWs' articles. Since the TAWs had 98 occurrences of attitude markers in the Turkish research articles (cf. Çapar, 2014), it can be said that the TAWs tended to express their opinions on their propositions, and they also did 
AJESI - Anadolu Journal of Educational Sciences International, 2020; 10(1): 324-358

DOI: 10.18039/ajesi.682042

the same while writing in English. This may explain why the TAWs used more attitude markers than the AAWs.

As for statistical analysis, Table 6 illustrates that the TAWs used attitude markers slightly more frequently compared to the AAWs (72 vs. 58 times), but with no significant difference $(\mathrm{z}=1.228285, \mathrm{p}<0.05)$.

Table 6

Binomial Test Results for the Use of Attitude Markers in ERAs by TAWs and AAWs

\begin{tabular}{lrll}
\hline & Frequency & qi & $\mathrm{z}$ \\
\hline TAWs & 72 & 0.00072 & 1.228285 \\
AAWs & 58 & 0.00058 & \\
\hline
\end{tabular}

Figure 3 shows the attitude markers used by both groups of writers. Both writer groups used important as the most frequent adjective to express their attitude towards the proposition, and the frequency of the occurrence of this adjective is almost the same for both groups. The Near synonym of important were also used, such as significant, vital, crucial, noteworthy, albeit less frequently. Both writer groups also tended to express surprise (such as unsurprising, surprising).

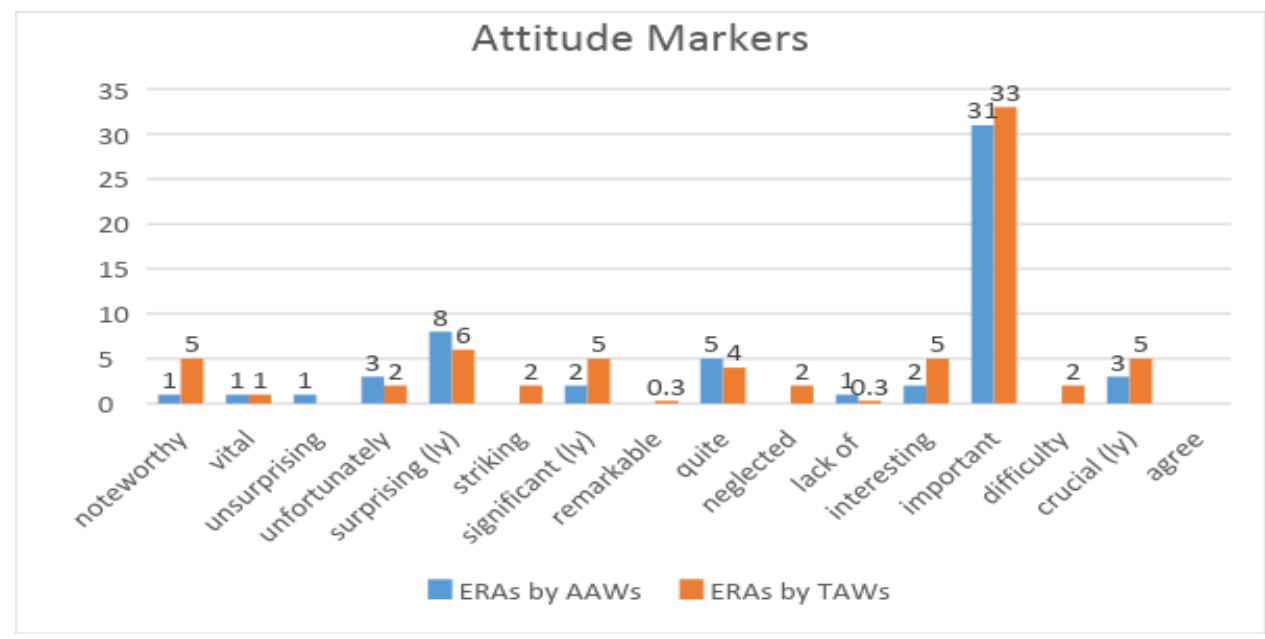

Figure 3: Attitude Markers in ERAs 
AJESI - Anadolu Journal of Educational Sciences International, 2020; 10(1): 324-358

DOI: 10.18039/ajesi.682042

When the data was compared in terms of the use of attitude markers, it was found that both sets of writers used these markers quite often and with a variety. This finding is similar to that of Hyland (2005) in natural sciences and social sciences. Hyland found that writers of social sciences used attitude markers frequently and with a variety. He explains the reason for this by stating that these writers needed to establish a "convincing discourse and personal credibility, critical insight and disciplinary competence" (Hyland, 2005: 151), which can be constructed by the use of attitude markers.

\section{Self-mention}

Self-mention in general is considered to be the choice of the writer to take a particular stance and to situate authorial identity (Hyland, 2001). The findings of the study show that both the AAWs and the TAWs used self-mention. There are two ways preferred; the use of first person pronouns and the pattern the researcher. Table 7 shows that there is significant difference between the ratios of self-mention markers used by the TAWs and AAWs. $(\mathrm{z}=-$ $8.22765, \mathrm{p}<0.05)$

Table 7

Binomial Test Results for the Use of Self-mention Markers in ERAs by TAWs and AAWs

\begin{tabular}{lrlr}
\hline & Frequency & qi & z \\
\hline TAWs & 95 & 0.00095 & $-8.22765^{*}$ \\
AAWs & 247 & 0.00247 & \\
\hline
\end{tabular}

The AAWs used first-person pronouns to express their presence in the texts much more frequently than the TAWs. Hyland (2000) expresses that writers' personal presence and authority is considered as a vital rhetorical resource for writers to gain approval for their work. In line with this, Hyland (2002) found in his study that while native academic writers use first person pronouns, they had little impact on students' writing. He explains the reason 
AJESI - Anadolu Journal of Educational Sciences International, 2020; 10(1): 324-358

DOI: 10.18039/ajesi.682042

for this as the possibility of acquiring implicit understanding of disciplinary conventions through reading and that the variations were rarely spelt out for students. This may also be the case for the findings of this study. Another explanation for the finding can be the uncertainty in the literature on the use of self-mention in academic texts. While impersonality is considered to be a feature of expository writing, because it is thought that academic research is empirical and objective (Geertz, 1988), and many textbooks teach learners to avoid selfmention, some textbooks direct learners to make their voice clear by use of the first person (Hyland, 2002). On the other hand, self-mentions may seem too authoritative in Turkish culture, and TAWs may not find them appropriate.

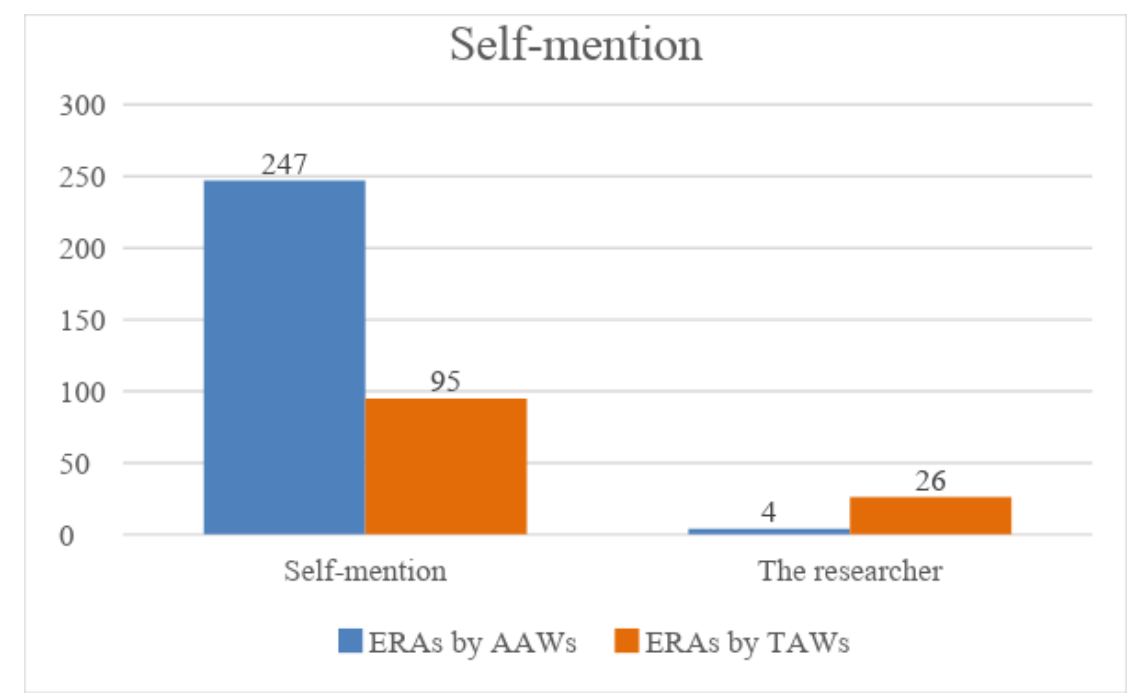

Figure 4: Self-mention in ERAs by TAW and AAWs

Figure 4 shows that instead of the first person pronoun, the TAWs tended to use the pattern the researcher in their texts, too. However, this pattern does not necessarily mean expressing presence in the text, because the writers used to express their role in explaining the study. It was found that the TAWs preferred not to use first person pronouns in their Turkish research articles either. There were 19 occurrences (cf. Çapar, 2014). This finding may indicate that expressing self in Turkish research articles may not be acceptable as an academic style and therefore, the TAWs avoided using it. Nonetheless, since it is acceptable in English 
AJESI - Anadolu Journal of Educational Sciences International, 2020; 10(1): 324-358

DOI: 10.18039/ajesi.682042

academic writing, the TAWs may have felt more confident about this issue, and therefore used self-mention markers more frequently in their English research articles.

\section{Engagement Markers}

By using engagement markers, writers have the choice to highlight or downplay the presence of their readers in the text (Hyland, 2005). Engagement markers for both writer groups were compared in terms of frequency. The AAWs had 99 occurrences and the TAWs had 122 occurrences of engagement markers in their articles. Although there is a difference in the use of engagement markers in the articles by the TAWs and the AAWs in terms of frequency, no significant difference was found between the groups after the binomial test was $\operatorname{run}(\mathrm{z}=1.548012, \mathrm{p}<0.05)$ as can be seen in Table 8.

Table 8

Binomial Test Results for the Use of Engagement Markers in ERAs by TAWs and AAWs

\begin{tabular}{lcll}
\hline & Frequency & qi & $\mathrm{z}$ \\
\hline TAWs & 122 & 0.00122 & 1.548012 \\
AAWs & 99 & 0.00099 & \\
\hline
\end{tabular}

However, the categories of engagement markers should also be compared to find out whether the writer groups used similar or different engagement markers in their texts. Figure 5 displays that both the TAWs and the AAWs used directives as the most frequent engagement marker, followed by the use of reader pronouns. In terms of the use of direct questions and personal asides, slight differences can be observed. 
AJESI - Anadolu Journal of Educational Sciences International, 2020; 10(1): 324-358

DOI: 10.18039/ajesi.682042

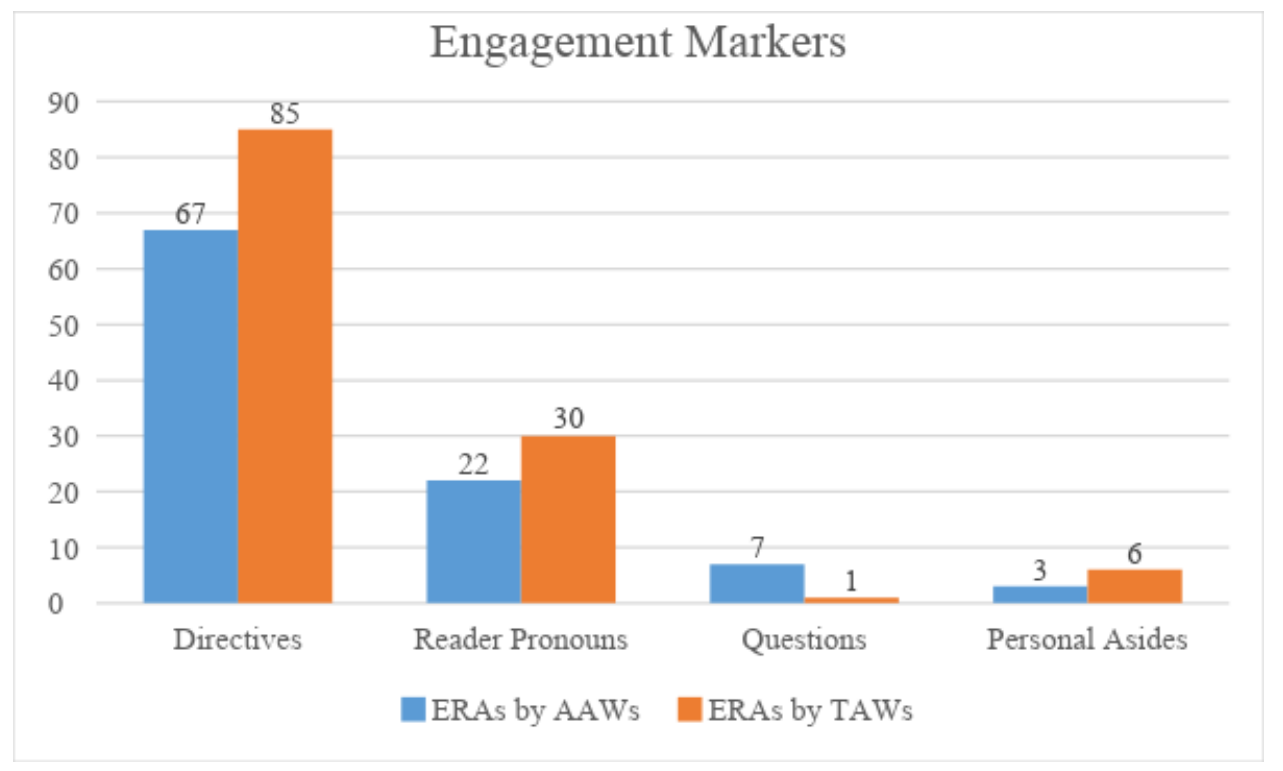

Figure 5: Engagement marker use by TAWs and AAWs

The results of the binomial test shows that there was no significant difference between the subcategories of engagement markers, such as directives, reader pronouns, and personal aside, except for questions as presented in Table 9.

Table 9

Binomial Test Results for Subcategories of Engagement Markers Used in by TAWs and AAWs

\begin{tabular}{lclcccc} 
& \multicolumn{2}{c}{ TAWs } & \multicolumn{4}{c}{ AAWs } \\
\cline { 2 - 6 } & Frequency & \multicolumn{2}{c}{ qi } & Frequency & qi & Z \\
\hline Directives & 85 & 0.00085 & 67 & 0.00067 & 1.460556 \\
Reader Pronouns & 30 & 0.0003 & 22 & 0.00022 & 1.109548 \\
Questions & 1 & 0.00001 & 7 & 0.00007 & $-2.12139^{*}$ \\
Personal Aside & 6 & 0.00006 & 3 & 0.00003 & 1.000025 \\
\hline
\end{tabular}

As stated above and as can be seen in Table 9, the only subcategory that showed significant difference between the two groups was the use of questions. The AAWs preferred to ask questions to pull their readers' attention to the article more frequently compared to the TAWs. Asking questions in research articles may seem to be too informal for the TAWs, because TAWs may think that questions are usually used in colloquial everyday discourse. 
AJESI - Anadolu Journal of Educational Sciences International, 2020; 10(1): 324-358

DOI: 10.18039/ajesi.682042

In terms of the use of directives, the structure types preferred by the AAWs and the TAWs were compared. Figure 6 above shows the type of directives used by both writer groups. It can be seen that both groups used the imperative form of verbs the most frequently in their articles. The imperative form of verb see is the mostly used form with the aim of referring to tables, figures, sources, etc. The AAWs also used the imperative form of the verbs note that, consider that, etc. to attract the attention to the importance of opinions and facts, whereas the TAWs only used the imperative to lead their readers to the information related to visual sources, such as tables and figures. The use of the passive is more frequent in the text of the TAWs, which can be interpreted as a preference by Turkish writers instead of using imperatives, which may be considered to be assertive and impolite in Turkish culture. As Hyland (2001: 565) states "directives carry strong connotations of unequal power, claiming greater authority for the writer by requiring readers to act or see things in a way determined by the writer." As a result, most directives were used for citational purposes in the data, similar to the findings of Hyland (2001).

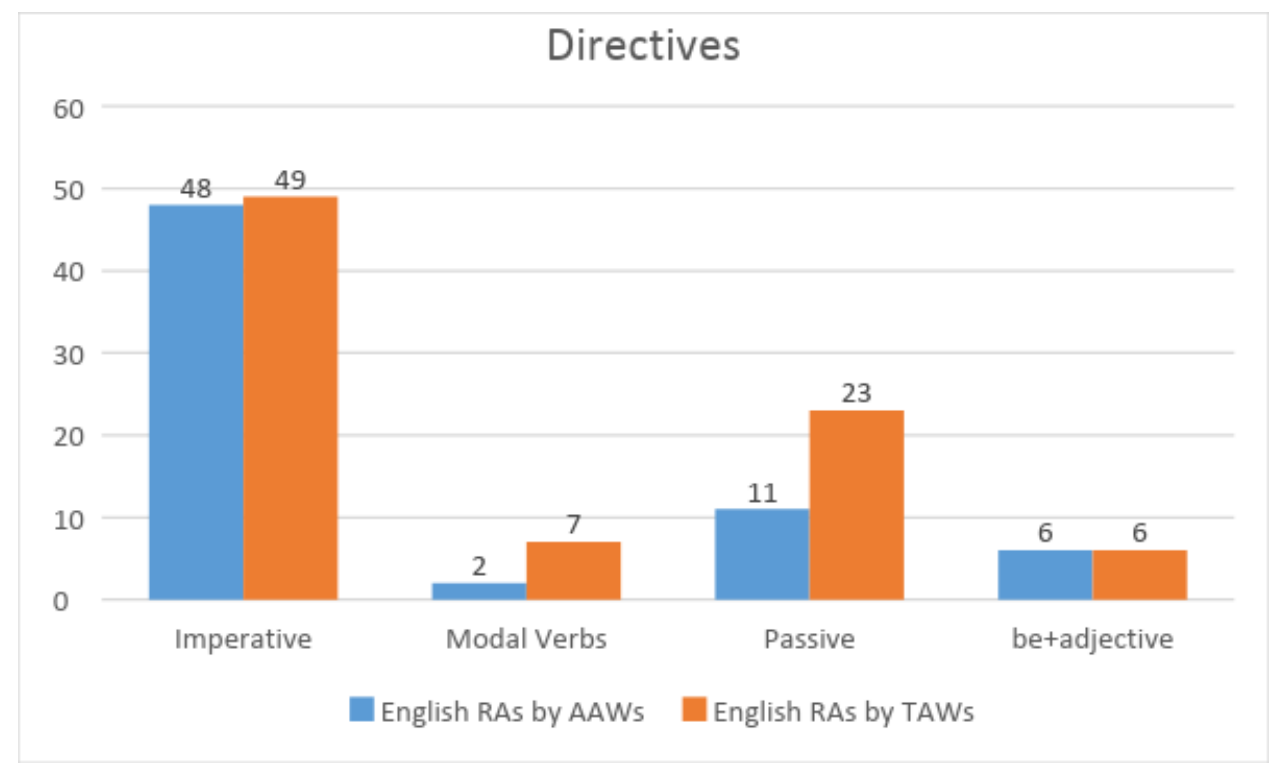

Figure 6: Use of directives

As presented in Figure 6, reader pronouns were also frequently used by the writers, and the TAWs used more reader pronouns compared to the AAWs. However, asking direct 
AJESI - Anadolu Journal of Educational Sciences International, 2020; 10(1): 324-358

DOI: 10.18039/ajesi.682042

questions was more frequently used by the AAWs. In terms of personal asides (incidentally, it is true that etc.), the TAWs' texts included more occurrences.

\section{Discussion and Suggestions}

This study shows that both the TAWs and AAWs under consideration used IMMs in their research articles. They opened discussions on their propositions and they both toned down their voice by hedges and showed certainty of their opinions by the use of boosters; they showed their presence, directed their readers in their texts and engaged them by using directives, reader pronouns, direct questions and personal asides, although the last two markers were used the least in the data.

In terms of the use of hedge markers, it was found that TAWs used more hedge markers. While the AAWs used can less than may, the TAWs used both of these modal verbs frequently. This finding is to some extent be similar to the study of Crawford (2005), (see Vold (2006- medical research article; Biber et al.1999). TAWs tend to use modal verbs to express hedging in English, as did the AAWs, but by using less variety than the AAWs. The finding relating to a lack of variety is in line with the finding of Karkkainnen (1990), who found that Finish learners equally used less variety compared to native speakers of English. Another explanation maybe the view that hedges help writers to take their stances and project their claims with a suitable amount of certainty and confidence; hence, it gives writers the opportunity to protect themselves against possible critical reactions (Hyland, 2005). This seems to be the reason why both writer groups used hedging in their research articles.

Boosters were found to be the least used by both writer groups, with the finding that the TAWs used boosters less than the AAWs. Writers have the need to convince their readers of the true value of their propositions (Vazquez and Giner, 2009). Academic writers may tend to use boosters less frequently compared to other IMM devices because these express high 
AJESI - Anadolu Journal of Educational Sciences International, 2020; 10(1): 324-358

DOI: 10.18039/ajesi.682042

certainty of the proposition they are making, and the writers may feel they prevent interaction between writer and reader because the writer closes the proposition to discussion. The TAWs preferred not to show full commitment to their propositions and avoided displaying authority. This finding is different from the findings of Zarei (2011) but is in line with Can (2006).

In terms of attitude markers, it was found that the TAWs did not make use of a variety of markers. The most frequently marker used was important by TAWs while the AAWs used a greater variety in expressing their attitudes, such as surprise, significance, agreement, frustration, expectancy etc.

An outstanding difference was in the use of self-mention by the writers. While the AAWs used first person pronouns extensively, the TAWs used fewer in English. This may indicate that the TAWs preferred not to show their presence in academic texts. As Hyland (2002) suggests, writers need to construct a stance toward their propositions, but if the writer is from a culture (such as Turkish) which relies more on circumstances where self is more collectively constructed, the writer tends to avoid mention of self in texts (Ramanathan and Atkinson, 1999). Another reason for the sparse use of self-mention markers by the TAWs may be academic writing conventions of their culture, since they may have been taught not to make themselves explicit while writing academic texts. This impersonal style is considered a characteristic of expository writing because it is based on the notion that academic research is purely empirical and objective (Hyland, 2002). Self-mention is considered as being representative of writers to readers and, by means of the use of first person pronouns, writers have the opportunity to display their roles in the discourse (Hyland, 2001; Kuo, 1999; Tang and John, 1999). This may be the reason why in certain cultures avoidance of the self is taught in academic writing.

Finally, both the AAWs and the TAWs used engagement markers commonly in their texts, although the devices they used showed differences in frequency. It is possible that 
AJESI - Anadolu Journal of Educational Sciences International, 2020; 10(1): 324-358

DOI: 10.18039/ajesi.682042

engagement markers were used more often because by using engagement markers, writers can attract their readers' attention to important points of their argument using questions, directives among others (Hyland, 2005). In this study, writers generally preferred to use directives, in particular to attract their readers' attention to tables or outside references. While both sets of writers used directives frequently, the TAWs mostly preferred to direct their readers using the passive form of verbs (as shown in Table 3, etc.). TAWs may think that directing readers to tables or figures by using the passive can sound more academic and polite.

All the results of this study as well as those of previous studies show that both writer groups focus on building interaction with their readers. The AAWs used IMMs significantly more frequently than TAWs in this study. This finding is similar to those of Blagojevic (2004), Dahl (2004), Mur-Duenas (2011). Considering this study, the differences in the use of interactional metadiscourse markers in this study may also be considered as being culturespecific. By analyzing written texts, we can learn a lot about the cultures of the writers and their writing conventions. As Mauranen (2001) puts forward "texts are...one of the main keys to understanding a culture. Texts as cultural products act out relevant social relationships within the culture, and in this way provide keys to understanding themselves as well as other aspects of the culture" (p.53). In terms of academic writing, writing norms may show differences from culture to culture, in traditional writing habits and in rhetorical preferences which exist in different writing cultures (Blagojevic, 2004; Halliday, 1994; Ivanic, 1998; Kaplan, 1966; Flottum, Dahl, Kinn, 2006). When the interactional markers are taken into consideration, the analysis of the study shows that there are subtle differences that may be considered as a reflection of the cultural backgrounds of the writers. Academic writers may transfer their own cultural writing norms while writing in a different language. For example, while the writer is responsible for conveying the message to the reader and aiding them in its comprehension by using metadiscourse markers in Japanese, Korean and Chinese, this 
AJESI - Anadolu Journal of Educational Sciences International, 2020; 10(1): 324-358

DOI: 10.18039/ajesi.682042

explicitness may be perceived as acceptable since the reader should be assisted in receiving the message (Eggington, 1987). Clyne (1987) states that German writers require readers to comprehend the meaning of their texts on their own, while in English culture it is the responsibility of the writer to convey meaning. In this case, the taxonomy of Hyland and Tse (2004) may be considered as limited and there may be the need to adapt this taxonomy to the culture of the language that the text is written in.

Considering the effect of culture, the findings of this study showed that TAWs avoid the use of self in academic writing. In Turkey, the avoidance of self-mention in academic texts is taught, because these markers may appear as too strong for readers and may not be acceptable to other scholars. The data of this study shows that TAWs prefer to avoid selfmention and voice or the term the researcher. Moreover, TAWs avoided the use of imperative forms of verbs when they needed to attract readers' attention on a proposition; such as note that, notice that and so forth. Instead of using these devices, they preferred to use attitude markers and adjectives. An inference from this finding might be that writers should not only be aware of the writing conventions of English academic writing, but also of the culture that they expect their audiences to be from (Hyland, 2005), or that writers should be taught that metadiscourse displays differences among cultures in terms of academic writing.

Another explanation for the less use of IMMs of TAWs can be the academic education received. In Turkey, only limited formal education in writing is provided both in foreign language courses and Turkish courses. There is less emphasis put on writing conventions in native language education. This may explain why TAWs use less interactional metadiscourse markers in their texts compared to AAWs.

Academic writing conventions are quite global (Kaplan, 1966; Suntara and Chokthawikit, 2018; Widdowson, 1979). Also other studies found that academic non-native speaker writers use similar conventions (in Chinese, Liu and Huang, 2017;in Turkish, Kan, 
AJESI - Anadolu Journal of Educational Sciences International, 2020; 10(1): 324-358

DOI: 10.18039/ajesi.682042

2016) as well as the other previously conducted studies mentioned above. All these studies show that academic writers attempt to establish a connection with their audience. Still, every culture has its own norms and no writers have to adapt their writing norms to a target language. However, if academic writers want to publish in international journals, then knowing the academic writing conventions of the target language is important. Başaran and Sofu (2009) investigated why English research articles of TAWs were less accepted by the SSC journals compared to other countries. They found that in 2005 , Turkey ranked $19^{\text {th }}$ of 190 countries in terms of articles accepted in the Science Citation Index and $25^{\text {th }}$ of 159 countries for Social Sciences Citation Index journals. One point that the study shows is the formal training received. They found that one emerging theme in their study was that academic writers did not receive formal academic training thereby causing difficulties for TAWs in academic writing.

\section{Implications of the Study}

The most important difference between Turkish and American academic writers is that the former tended to use less interactional metadiscourse. They tended to show less presence in their articles as writers, for example, by using the passive form of verbs rather than the first person pronouns in active sentences. This is a cultural difference: the use of the passive voice is considered to be a sign of modesty in Turkish culture. This stylistic difference is an aspect of academic discourse, which may not necessarily need further instructional intervention. In addition, it has been found that AAWs used more diverse interactional markers compared to TAWs.

The academic texts included in this study have already been published in respected journals and thus their writers including non-native speakers are either well aware of the conventions of academic discourse or their texts have been meticulously edited. It is our 
AJESI - Anadolu Journal of Educational Sciences International, 2020; 10(1): 324-358

DOI: 10.18039/ajesi.682042

assumption that these writers are well informed about both the rules and conventions of English academic discourse in their discipline since they have advanced degrees in the English language teaching profession, albeit they tended to use less diverse interactional markers compared to native speakers.

However, writers from other professions may not necessarily be such competent speakers / writers and they may not have mastered the language, let alone the conventions of academic discourse. These writers need further instruction on certain conventional aspects of academic writing. They also need more diverse ways in which they can use the markers of hedging, boosting, attitude or to engagement to become even better writers. Writers further need to use appropriate language in order to be accepted by academic journals and to reach a wider audience in the international community of researchers. Therefore, it is suggested that academic writing courses be included especially in MA and $\mathrm{PhD}$ programs, including analyses of English academic texts as well. Academic writers can be assisted by being exposed to models of academic texts and raising their consciousness on both micro and macro aspects of academic discourse, including interactional metadiscourse markers.

Such instruction could also be given in undergraduate programs, especially in English Medium Instruction courses, students need to read on their disciplines and they are expected to write academic papers in order to fulfill the requirements. Unfortunately, as Başaran and Sofu (2009) state TAWs do not receive much information on academic writing in their courses at university, at graduate and undergraduate levels. As a result, including courses on academic writing in the curriculum may help to improve the English academic writing skills of Turkish academicians. 
AJESI - Anadolu Journal of Educational Sciences International, 2020; 10(1): 324-358

DOI: 10.18039/ajesi.682042

\section{Limitations of the Study}

The scope of this study is limited to the analysis of academic texts within the field of English Language Teaching. Further studies can be carried out across disciplines such as in Flottum et al. (2006), Mina and Biria (2017), and Suntara and Chokthawikit (2018). In order to make generalizations on general academic texts, analyses of texts in other disciplines should be taken into consideration.

\section{References}

Alg1, S. (2012).Hedges and boosters in L1 and L2 argumentative paragraphs: Implications for teaching L2 academic writing.Unpublished MA Thesis. Middle East Technical University, Turkey.

Başaran, S. and Sofu, H. (2009). The process of writing research articles in English and getting published: A case study. Gaziantep Üniversitesi Sosyal Bilimler Dergisi, 8 (2), $371-384$.

Benfield, J. R. and Feak, C. B. (2006). How authors can cope with the burden of English as an international language. Chest, 129, 1728-1730.

Benfield, J. R. and Howard, K. M. (2000).The language of science.European Journal of Cardio-thoracic Surgery, 18, 642-648.

Biber, D., Johansson, S., Leech, G., Conrad, S. and Finegan, E. (1999). Longman grammar of spoken and written English, Pearson Education Ltd.

Blagojevic, S. (2004). Metadiscourse in academic prose: A contrastive study of academic articles written in English by English and Norwegian speakers. Studies about Linguistics, 5, 1-7.

Breivega, K., Dahl, D. and Flottum, K. (2002).Traces of self and others in research articles. A comparative pilot study of English, French, Norwegian research articles in medicine, 
AJESI - Anadolu Journal of Educational Sciences International, 2020; 10(1): 324-358

DOI: 10.18039/ajesi.682042

economics and linguistics. International Journal of Applied Linguistics, 12(2), 218239.

Bunton, D. (1999). The use of higher level metatext in $\mathrm{PhD}$ theses. English for Specific Purposes, 18, 41-56.

Can, H. (2006). An analysis of freshman year university students' argumentative essays. Unpublished MA thesis, Boğaziçi University, Turkey.

Chambliss, M. J. and Garner, R. (1996). 'Do adults change their minds after reading persuasive text?' Journal of Written Communication, 13 (3), 291-313.

Chesterman, A. (1998). Contrastive Functional Analysis. Amsterdam: J. Benjamin Publishing.

Clyne, M. (1987).Cultural differences in the organization of academic texts. Journal of Pragmatics, 11, 211-247.

Crawford, C. (2005). Adjusting a business lecture for an international audience: A case study. English for Specific Purposes 24, 183-199.

Creswell, J. W. (2005). Educational Research: Planning, Conducting, and Evaluating Quantitative and Qualitative Research. Pearson Education International: New Jersey.

Crismore, A. and Farnsworth, R. (1989). Mr Darwin and his readers: Exploring interpersonal metadiscourse as a dimension of ethos. Rhetoric Review, 8(1), 91-112.

Crismore A., Markkanen, R. and Steffensen, M. (1993). Metadiscourse in persuasive writing: A study of texts written by American and Finnish university students. Written Communication, 10 (1), 39-71.

Çapar, M. (2014). A Study on Metadiscourse Markers in Research Articles. Unpublished PhD thesis, Anadolu University: Eskişehir, Turkey.

Dahl, T. (2004). Textual metadiscourse in research articles: a marker of national culture or of academic discipline? Journal of Pragmatics, 36, 1807-1825. 
AJESI - Anadolu Journal of Educational Sciences International, 2020; 10(1): 324-358

DOI: 10.18039/ajesi.682042

Doyuran, Z. (2009). Conciliation of knowledge through Hedging in Turkish Scientific Articles. Edebiyat Fakültesi Dergisi/Journal of Faculty of Letters, 26(1), 85-99.

Eggington, W. (1987).Written academic discourse in Korean: Implications for effective communication. In U. Connor and R. Kaplan (eds.). Writing across languages: Analysis of L2 text. Reading, MA: Addison-Wesley.

Flottum, K., Dahl, T. and Kinn, T. (2006).Academic Voices.Across Languages and Disciplines. Amsterdam/Phildelphia: John Benjamins.

Flowerdew, J. (1999). Writing for scholarly publication in English: The case of Hong Kong. Journal of Second Language Writing, 8, 123-145.

Fuertes-Olivera P. A., Velasco-Sacristan, M., Arribas-Bano, A. and Samaniego-Fernandez, E. (2001). Persuasion and advertising English: Metadiscourse in slogans and headlines. Journal of Pragmatics, 33, 1291-1307.

Geertz, C. (1988). Words and Lives: The Anthropologist as Author. Stanford University Press, Palo, Alto, CA.

Halliday, M. A. K. (1973). Explorations in the functions of language. New York: Elsevier North-Holland.

Halliday, M. A. K. (1994). An introduction to functional grammar (2nd ed). London: Edward Arnold.

Hinkel, E. (2005). Hedging, inflating, and persuading in L2 academic writing. Applied Language Learning, 15 (1), 29-53.

Hyland, K. (1998). Persuasion and context: the pragmatics of academic metadiscourse. Journal of Pragmatics, 30, 437-455.

Hyland, K. (1999). Disciplinary Discourses: Writer stance in research articles. In C. Candlin and K. Hyland (Eds.).Writing: Texts, Processes and Practices, 99-121. London: London Group. 
AJESI - Anadolu Journal of Educational Sciences International, 2020; 10(1): 324-358

DOI: 10.18039/ajesi.682042

Hyland, K. (2000). Disciplinary Discourses: Social Interactions in Academic Writing. Longman, London.

Hyland, K. (2001). Humble servants of the discipline? Self-mention in research articles. English for Specific Purposes, 20 (3), 207-226.

Hyland, K. (2002). Authority and invisibility: Authorial identity in academic writing. Journal of Pragmatics, 34, 1091-1112.

Hyland, K. and Tse, P. (2004). Metadiscourse in academic writing: a reappraisal. Applied Linguistics, 25 (2), 156-177.

Hyland, K. (2005). Metadiscourse. Continuum: London.

Ivanic, R. (1998).Writing and Identity: The Discoursal Construction of Identity in Academic Writing. Amsterdam: Benjamins.

Kafes, H. (2009). Authorial stance in academic English: native and non-native academic speaker writers' use of stance devices (modal verbs) in research articles. Unpublished PhD thesis, Anadolu University: Eskişehir, Turkey.

Kan, M. O. (2016). The Use of Interactional Metadiscourse: A Comparison of Articles on Turkish Education and Literature. Educational Sciences: Theory \&Practice. 16(5), 1639-1648.

Kaplan, R. (1966). Cultural thought patterns in inter-cultural education. Language Learning, $16(1-2), 1-20$.

Kaplan, R., and Baldauf, R. B. (2005). Editing contributed scholarly articles from a language management perspective. Journal of SecondLanguage Writing, 14, 47-62.

Karasar, N. (1995). Bilimsel Araştırma Yöntemi. Ankara.

Karkkainen, E. (1990). Modality as a strategy in spoken interactions.MA thesis. Oulu: University of Oulu. 
AJESI - Anadolu Journal of Educational Sciences International, 2020; 10(1): 324-358

DOI: 10.18039/ajesi.682042

Kreutz, H.and Harres, A. (1997). Some observations on the distribution and function of hedging in German and English academic writing.A Duszak (Ed.), Culture and styles of academic discourse.Trends in linguistics. Studies and monographs 104, Mouton de Gruyter, Berlin/New York (1997), pp. 181-201.

Kuhi, D. and Behnam, B. (2011). Generic variations and metadiscourse use in the writing of applied linguists: A comparative study and preliminary framework. Written Communication, 28(1), 97-141.

Kuo, C. (1999). The use of personal pronouns: role relationships in scientific journal articles. English for Specific Purposes 18 (2), 121-138.

Liu, P. and Huang, X. (2017). A Study of Interactional Metadiscourse in English Abstracts of Chinese Economics Research Articles. Higher Education Studies, 7(3), 25-41.

Mauranen, A. (1993). Contrastive ESP rhetoric: Metatext in Finnish-English economic texts. English for Specific Purposes, 12, 3-22.

Mauranen, A. (2001). Desciptions or explanations?Some methodological issues in contrastive rhetoric. In Hewings, M. (Eds.).Academic writing in context. University of Birmingham Press: Birmingham. (43-54).

Mina, K. G. and Biria, R. (2017). Exploring Interactive and Interactional Metadiscourse Markers in Discussion Sections of Social and Medical Science Articles. International Journal of Research in English Education. 2(4), 11-29.

Mur-Duenas, P. (2011). An intercultural analysis of metadiscourse features in research articles written in English and Spanish. Journal of Pragmatics, 43, 3068-3079.

Ramanathan, V. and Atkinson, D. (1999).Individualism, academic writing and ESL writers. Journal of Second Language Writing, 8, 45-75. 
AJESI - Anadolu Journal of Educational Sciences International, 2020; 10(1): 324-358

DOI: 10.18039/ajesi.682042

Rezzano, N. S. (2004). Modality and modal responsibility in research articles in English. In Fachinetti, R \& Palmer, F. (eds.) English modality in perspective. Genre analysis and contrastive studies, 101-118.. Germany: Peter Lang GmbH.

Schiffrin, D. (1980). Metatalk: Organizational and evaluative brackets in discourse. Sociological Inquiry, 50, 199-236.

Seibel, C. (1980). Subjective Modality. Kansas Working Papers in Linguistics, 5, 15-20.

St. John, M. (1987). Writing processes of Spanish scientists publishing in English. English for Specific Purposes, 6, 113-120.

Suntara, W. and Chokthawikit, S. (2018). Interactional Metadiscourse in Research Article Abstracts: An Analysis from Public Health Journals. Language and Linguistics, 36,3152.

Swales, J. (1990).Genre Analysis: English in Academic and Research Settings. Cambridge: CUP.

Tang, R. and John, S. (1999). The 'I' in identity: exploring writer identity in student academic writing through the first person pronoun. English for Specific Purposes, 18, 23-39.

Valero-Garces, C. (1996). Contrastive ESP rhetoric: Metatext in Spanish-English economics texts. English for Specific Purposes, 15 (4), 279-294.

Vande Kopple, W. T. (1985). Some exploratory discourse on Metadiscourse.College Composition and Communication, 36 (1), 82-93.

Van Dijk, T., Ting-Toomey, S., Smitherman, G. and Troutman, D. (1997).Discourse, ethnicity, culture, and racism. In van Dijk (Ed.).Discourse as social action. London: Sage Publications.

Vassileva, I. (2001). Commitment and detachment in English and Bulgarian academic English. English for Specific Purposes, 20, 83-102. 
AJESI - Anadolu Journal of Educational Sciences International, 2020; 10(1): 324-358

DOI: 10.18039/ajesi.682042

Vazquez, I. and Giner, D. (2009). Writing with conviction: The use of Boosters in Modelling Persuasion in Academic Discourses. Revista Alicantina de Estudios Ingleses, 22, 219237.

Ventola, E. (1997). Modalization: Probability-an exploration into its role in academic writing. In A. Duszak, Culture and styles of academic discourse.Trends in linguistics. Studies and monographs 104 (pp. 157-179). Berlin/New York: Mouton de Gruyter.

Vold, E. T. (2006). The choice and use of epistemic modality markers in linguistic and medical research articles. In Hyland, K. and Bondi, M. (eds.) Academic discourse across disciplines. Switzerland: Peter Lang, AG.

Widdowson, H. G. (1979). Explorations in applied linguistics. Oxford: Oxford University Press.

Yıldırım, A. and Şimşek, H. (2005).Sosyal Bilimlerde nitel araştırma yöntemleri. Seçkin: Ankara.

Zarei, G. R. (2011). A contrastive study on metadiscourse elements used in humanities vs. non humanities across Persian and English. English Language Teaching, 4 (1), 42-50. 